УДК 908 (477) «18/19»

https://doi.org/10.34142/2313-2345.2019.56.02

Місостов Т.Ю.

кандидат історичних наук, дочент, дочент кафедри всесвітньої історії Харківського національного педагогічного університету імені Г. С. Сковороди orcid.org/0000-0003-0595-7744

\title{
РОЛЬ ОРГАНІВ ЗЕМСЬКОГО САМОВРЯДУВАННЯ ГУБЕРНІЙ ЛІВОБЕРЕЖНОЇ УКРАЇНИ В ОРГАНІЗАЦІЇ МІСЦЕВИХ КРАЕЗНАВЧИХ ЦЕНТРІВ ТА РОЗГОРТАННІ ДОСЛІДЖЕНЬ З ЛОКАЛЬНОЇ ІСТОРІЇ В КІНЦІ ХІХ - НА ПОЧАТКУ ХХ СТ.
}

Стаття присвячена аналізу ролі земських органів самоврядування Харківської, Полтавської та Чернігівської губерній в організаиії та подальшому розвитку історико-краєзнавчих осередків в даних губерніях, а також внеску місиевих земств у роботу з вивчення локальної історії в Лівобережній Україні. Висвітлені та проаналізовані факти фінансової допомоги або безпосередньої участі земств у створенні та утриманні окремих музеїв, вчених архівних комісій та інших осередків регіональної історії. Розглянуто окремі напрями земської діяльності, щзо сприяли здійсненню краєзнавчих наукових розвідок та експедииій, популяризації історії краю на шпальтах місиевої преси, улаштуванню археологічних з їздів та етнографічних виставок та, в цілому, розгортанню історикокраєзнавчого руху в губерніях Лівобережжя.

Ключові слова: земство, краєзнавчій осередок, локальна історія, музей, вчена архівна комісія, місчева давнина, історико-краєзнавчий рух.

The article is devoted to the analysis of the role of the zemstvo self-government bodies of Kharkiv, Poltava and Chernihiv regions in the organization and further development of local history centers in these provinces, as well as the contribution of local zemstvos to the study of local history in the Left-Bank Ukraine. Covered and analyzed the facts of financial assistance or direct participation of zemstvos in the creation and maintenance of individual museums, scientists archival commissions and other centers of regional history. The positive significance of the zemstvos contribution to the development of museum affairs has been determined, which contributed to the rise of the historical and ethnographic movement. On the one hand, an important part of this movement developed, on the other hand, some zemstvo museums became the leading centers of historical and ethnographic research in the provinces.

Some areas of zemstvo activities that contributed to the conduct of regional scientific intelligence and expeditions, popularize the history of the region in the pages of the local press, the arrangement of archaeological congresses and ethnographic exhibitions and, in general, the development of historical and local history movement in the provinces of Left Bank were considered. It was determined that zemstvos played a very important role in the development of historical regional studies in the provinces of the Left Bank of Ukraine. Almost since the beginning of their existence, Zemstvo institutions have launched an active ethnographic work, which had a significant positive significance for the systematic dissemination of historical and ethnographic movements in the provinces. The presence of zemstvos in a number of ethnographers led to the creation of historical and ethnographic trends in the work of these bodies of local self-government.

Keywords: zemstvo, local history center, local history, museum, scientific archival commission, local antiquity, local history movement.

Постановка проблеми. Вивчення локальної історії є важливою складовою у висвітленні повноцінної картини розвитку окремих регіонів України. Розгортання icторико-краєзнавчого руху залежить не тільки від наявності фахових та наукових кіл, а й від значної активності громадськосTi, яка прагне до тенденцій національного самовизначення. Бурхливий процес розквіту подібних тенденції на Україні відбувся саме у другій половині XIX - на початку
XX століть. Реформи 60-70-х рр. XIX ст. не тільки прискорили соціально-економічний розвиток Російської держави, а значною мірою сприяли загальному піднесенню суспільно-політичного та культурного життя в Україні. Зростав інтерес до культури та історії краю серед різних верств українського населення.

Важливе значення для розвитку краєзнавчого руху в губерніях Лівобережної України мала діяльність новостворених ор- 
ганів місцевого самоврядування, зокрема, земств і органів міського управління. Саме 3 появою цих структур, вивчення місцевого краю стало більш різнобічним і набуло системного характеру. Більш того, земські установи губерній Лівобережжя у другій половині XIX - на початку XX ст. у своїй діяльності не тільки сприяли вивченню історії місцевого краю, а й самі розгорнули активну історико-краєзнавчу роботу. Тому безсумнівним є те, що для сучасної української історичної науки дослідження історико-краєзнавчих напрямів діяльності земських органів самоврядування $є$ актуальним i представляє значний науковий i практичний інтерес.

Аналіз актуальних досліджень. Загалом, питанню вивчення діяльності земських органів самоврядування присвячена чимала кількість дослідницьких праць. Утім, дослідження участі земств і органів міського самоврядування в організації та розвитку краєзнавчих центрів, а також розгортанні історико-краєзнавчого руху в цілому на Лівобережжі, ще не набули системного характеру. Серед публікацій, де висвітлюються окремі відомості щодо краєзнавчої діяльності земств, слід визначити дослідження розвитку історичного краєзнавства на Чернігівщині О. Коваленко [7] та В. Малиневської [8]. Деякі матеріали щодо участі земств у створенні та розвитку окремих краєзнавчих музеїв містять роботи М. Вайнштейна [2], Г. Скрипника [11], В. Бабенка [1], Г. Данилевського [3] та деяких інших. Утім, згадані автори в своїх дослідженнях розглядали більш широкі теми, тому саме земський внесок у розвиток краєзнавчих осередків i вивчення локальної історії представлений в роботах досить фрагментарно. Значно більше фактичного матеріалу з даної проблематики містить джерельна база нашого дослідження. Зокрема, це опубліковані праці та каталоги виставок XII і XIV археологічних з’їздів [6; 14], Праці Полтавської та Чернігівської вчених архівних комісій [12-13], документи Державного архіву Харківської області [4] тощо. Певні відомості щодо краєзнавчих заходів земств містять окремі періодичні видання досліджуваного періоду. Зокрема, це «Археологическая летопись Южной России» [5], «Киевская старина»
[9-10], «Український музей» [1-2], «Южный Край» [15] та інші.

Таким чином, відсутність узагальнюючих досліджень щодо внеску та, в цілому, ролі органів земського самоврядування губерній Лівобережної України в організації місцевих краєзнавчих центрів та розгортанні досліджень з локальної історії в кінці XIX - на початку XX ст, а також наявність значного фактичного матеріалу у джерелах й зумовили авторський інтерес до дослідження зазначеної теми.

Виклад основного матеріалу. Свій внесок у розвиток вивчення місцевої давнини земства Лівобережної України, зокрема земства Харківської, Полтавської і Чернігівської губернії здійснювали за кількома основними напрямками. Насамперед, це було фінансування окремих краєзнавчих центрів в даних губерніях, ініціатива та грошова допомога при створенні більшості музеїв краєзнавчого характеру, здійснення різноманітних історико-краєзнавчих заходів, активна участь у роботі Всеросійських археологічних з'їдів, які проводились в лівобережних губерніях, широка популяризація історико-краєзнавчого руху тощо.

Треба зазначити, взагалі більшість головних краєзнавчих осередків на Лівобережжі в тій чі іншій мірі отримували фінансування 3 боку органів земського самоврядування. Так, один з провідних центрів історико-краєзнавчих досліджень в Полтавській губернії, а саме Полтавська вчена архівна комісія, практично всі роки свого існування повністю утримувалась за рахунок губернського та повітових земств [12].

Головний історико-краєзнавчих осередок Чернігівської губернії, а саме Чернігівська вчена архівна комісія, також утримувалась на кошти, пожертвувані різними земствами губернії. Наприклад, у 1897 р. до Чернігівської вченої архівної комісії були асигновані грошові внески наступних земств: Глухівське - 100 крб., Городнянське - 25 крб., Конотопське - 100 крб., Новгородсіверське - 25 крб., Новозибківське 50 крб., Чернігівське - 50 крб., Сурожське 200 крб., Чернігівське губернське земство 300 крб., а також ще по 300 крб. щорічно $[13$, c. 5$]$. 
На Харківщині грошова допомога повітових та губернського земств була направлена, насамперед, на здійснення окремих історико-краєзнавчих заходів. Так, влітку 1900 р., виключно за рахунок грошової допомоги Харківського земства, було здійснено важливу за своїм значенням наукову експедицію до різних повітів Харківської губернії. Наукові дослідження під час експедиції планувалось проводити одночасно за кількома напрямами. Серед них - проведення археологічних розкопок курганів, розташованих в губернії, зібрання численного етнографічного матеріалу, даних щодо вивчення архівів, дослідження старовинних сховищ та культових обрядових місць, пам'ятників церковної давнини. При цьому, завдяки сприятливим матеріальним умовам, вдалося залучити до участі в роботі експедиції відомого українського історика, професора Університету св. Володимира В. Б. Антоновича, що мало неабияке значення щодо авторитетності цього заходу. Крім В. Б. Антоновича, також приймали участь у здійсненні досліджень такі визначні представники харківської історикокраєзнавчої наукової школи, як Є. М. Іванов, Д. П. Міллер, М. М. Плохинський, А. М. Покровський, Є. К. Рєдін, В. І. Савва, М. Ф. Сумцов, Є. П. Трефільєв, М. А. Федоровський та інші [4, арк. 4]. Результати досліджень були висвітлені на засіданнях XII археологічного з’їзду, зібрані етнографічні матеріали були спочатку представлені в якості експонатів на етнографічній виставці при з'їзді, а потім поповнили колекції провідних харківських музеїв [14].

В 1901 р. Харківським земством було виділено Попередньому комітету по улаштуванню XII археологічного з'їзду 2000 крб. на придбання предметів для вищезгаданої етнографічної виставки. В 1902 р. Полтавським губернським земством для поповнення колекції цієї виставки було виділено 1000 крб. [4, арк. 2].

Окрім фінансового спонсорства, земства Харківської, Полтавської і Чернігівської губерній виступали також в ролі засновників окремих дослідницьких центрів, діяльність яких була безпосередньо пов'язана 3 вивченням і збереженням історичних пам'яток місцевої давнини. Так, із метою збе- реження історичних пам'яток рідного краю, земства створювали спеціальні науковокультурні заклади - музеї. Краєзнавчі за характером своїх експозицій, ці осередки зібрали цінні колекції з географії, історії, культури та побуту краю, демонстрували їх під час навчального процесу в школах, показували відвідувачам музеїв, проводили різноманітні історико-краєзнавчі дослідження. Крім цього, в музеях були зібрані рідкісні документи 3 родинних архівів та бібліотеки зі старих поміщицьких садиб.

Органи місцевого самоврядування брали активну участь не тільки у заснуванні музеїв та подальшому їх утриманні, але й у матеріальній підтримці вже існуючих музеїв в губерніях. Так, багато в чому, саме завдяки підтримці з боку земств, в Чернігівській губернії існувала ціла мережа музейних закладів. Провідним центром музейної справи став Чернігів, де було зосереджено п'ять музеїв: Історико-археологічний музей Чернігівської архівної комісії (засновано в 1896 р.), Музей української старовини ім. В. В. Тарновського (1902р.), Єпархіальне давньосховище (1907р.), Природничо-історичний, сільськогосподарський і кустарний музей Чернігівського земства (1914р.), музей наочних посібників (1914 р.) [5,c.13]. Завдяки підтримці місцевих земств, музейні осередки виникали і в деяких повітових містах губернії. В 90-х роках XIX ст. в м. Конотопі було створено історичний музей, який мав комплектувати архівні матеріали, пам'ятки народного мистецтва, археологічні та етнографічні предмети, фіксувати фольклорно-етнографічні відомості [2; 10-11].

Подібний за своїм типом повітовий музейний осередок був створений в 1903 р. у м. Глухові. Рішення про заснування у Глухові Музею місцевої старовини і мистецтва було прийняте саме на повітових земських зборах. Головною метою музею було збереження речових і писемних пам'яток місцевої історії і культури. Це був невеличкий історико-краєзнавчий осередок, експозиції якого містили різні археологічні пам'ятки, предмети давнього домашнього побуту, зразки народного живопису, народні писанки, вишиванки, портрети місцевих куль- 
турних діячів, рідкісні архівні документи тощо [5].

На початку XX ст. з'являються також ніжинський (1909), остерський (1910), острозький (1913) та ряд інших земських музейних осередків збереження пам'яток місцевої старовини. У 1910 р. для забезпечення більшого збереження музейних експонатів, Чернігівське губернське земство прийняло рішення об'єднати музеї Чернігова. Це повинно було сприяти створенню в місті єдиного фундаментального музейного центру. Проте, з багатьох причин, практичне вирішення цього питання було реалізовано лише за часів радянської доби [11, c. 68].

У Харківській губернії розвиток музейної справи був пов'язаний, головним чином, 3 діяльністю Харківського університету, втім, саме завдяки активній участі органів місцевого самоврядування в Харкові було засновано Міський художньо-промисловий музей, офіційне відкриття якого відбулось у 1886 р. [3]. В 1911 р., при активній підтримці місцевого земства, виникає Вовчанський музей старовини. Основою для створення цього місцевого краєзнавчого осередку стала збірка археологічних пам'яток із розкопок Салтівського могильника, пожертвувана музею відомим дослідником місцевої давнини, археологом та етнографом В. О. Бабенком. Також, слід зазначити, що в 1912 р. місцеве земство розмістило музей у спеціально побудованому для цього триповерховому будинку [1].

В Полтавській губернії місцеве губернське земство відзначилось створенням у 1891 р. природничо-історичного музею Полтавського земства. Ідея створення цього музею належала професору В. В. Докучаєву. Земство щиро підтримало ініціативу видатного вченого й виділило кошти на придбання приміщення для цього закладу. В основу музею були покладені природничі колекції, зібрані під час експедиційних досліджень В. В. Докучаєва в Полтавській губернії. Згодом музей постійно поповнювався історико-краєзнавчими експонатами й утримувався коштом місцевого земства [9].

Слід зазначити, практично в усіх випадках експозиції земських музеїв були розміщені в приміщеннях, спеціально наданих для цього місцевими земствами. Існуючи за рахунок утримання земств, ці музейні заклади згодом зосередили в своїх фондах значну кількість унікальних краєзнавчих матеріалів. Музеї проводили культурноосвітні заходи, організовували екскурсії і лекції, публікували науково-популярні брошури, заохочували громадські кола до співробітництва тощо. Це сприяло популяризації історичного краєзнавства в губерніях, а також значно активізувало інтерес широких верств населення до вивчення рідної культури. Внесок місцевих повітових та губернських земств у розвиток музейної справи відігравав важливу роль у розгортанні в цілому історико-краєзнавчого руху в лівобережних губерніях. 3 одного боку, розвивалась важлива складова цього руху, з іншого - окремі земські музеї стали справжніми провідними центрами історико-краєзнавчих досліджень на Лівобережжі. Присутність у складі музейних закладів цілої плеяди видатних вчених-краєзнавців зумовила визначну активність музеїв у здійсненні численних історико-краєзнавчих досліджень.

Значну участь приймали земства у проведенні таких впливових, за своїм значенням, масштабних історико-краєзнавчих заходів, як Всеросійські археологічні з'їзди. Насамперед, земства відзначились своєю участю у роботі з'їздів, які проводилися на території Лівобережної України. Зокрема, це XII археологічний з'їзд (м. Харків, 1902 p.) та XIV археологічний з'їзд (м. Чернігів, 1908 р.). Так, у Чернігівському археологічному з'їзді активну участь прийняло Глухівське повітове земство. До з’ізду була підготовлена виставка яка складалася 3 історичного та етнографічного відділів. В основу одного з цих відділів, а саме історичного, були покладені експонати з музею Чернігівської архівної комісії, а також досить велика колекція місцевих старожитностей Глухівського повітового земства. Колекція містила понад 600 різноманітних предметів старовини [6].

Безумовно, активність земств у роботі археологічних з'їздів, певним чином, залежала від присутності у складі цих органів істориків-краєзнавців i, загалом, любителів вивчення рідного краю. Серед дослідників 
локальної історії, які співробітничали 3 земськими структурами Харківської, Полтавської і Чернігівської губерній, можна виділити таких фахівців, як В. Бабенко, В. Василенко, М. Ольховський, Л. Падалка, I. Павловський, О. Русов, О. Твердохлібов, П. Червінський, О. Шишкевич, М. Янчук та багато іншіх. Більшість з них брала безпосередню участь у підготовці та проведенні цих з’їздів. Так, у 1896-1898 рр. Полтавським губернським статистичним комітетом було зібрано вдосталь краєзнавчих матеріалів для видання праці Л.В.Падалки «Что сказало население Полтавской губернии о своём старом быте». Систематизацію цих матеріалів виконали у 1902 році земські діячі, члени Полтавської комісії з підготовки робіт XII археологічного з'їду, а саме: О. О. Русов, М. О. Русов, В. І. Василенко, М. О. Ольховський і Л. В. Падалка [12].

У 1902 році Полтавська тимчасова комісія відряджає В. І. Василенко на дослідження Литовського рубежу, який проходив через Полтавщину. Метою цієї експедиції було зібрання етнографічних особливостей населення i місцевостей 3 обох боків означеного рубежу. Члени комісії М. О. Ольховський і Л. В. Падалка провели дослідження давнього городища по р. Ворсклі біля с. Старих-Сентар і курганів по р. Коломаку, вивчили і сфотографували численні кам'яні баби по р. Орелі в Костянтиноградському повіті. Вони зібрали багато етнографічного матеріалу, зробили по можливості повну етничну картину краю. Цю колекцію привіз до етнографічного відділу Виставки археологічного з’їзду знавець етнографії Полтавщини Іван Антонович Зарецький [14, с. 270].

На XII археологічному з’їзді також було обговорено цілу низку важливих питань 3 організації та утворення різних краєзнавчих центрів для більш досконалого вивчення краю. Прикладом цього може бути промова голови II відділення «Древности этнографическия» Н. Я. Янчука про утворення в м. Харкові етнографічного музею [14, с. 323]. На користь розвитку історичного краєзнавства в Полтавській губернії, Радою з'їзду було прийнято рішення направити до міністра внутрішніх справ клопотання про відкриття Товариства любителів вивчення історії Полтавської губернії [14, c. 388]. Практичне втілення цього рішення було здійснене у відкритті у 1903 році Полтавської вченої архівної комісії, яка з самого початку свого існування стала одним 3 осередків краєзнавчої роботи на Полтавщині [12].

Досить вагомий внесок було зроблено земствами у поширенні й популяризації історико-краєзнавчих знань. Земські періодичні видання містили значну кількість відомостей 3 історичного минулого місцевого краю, що, безумовно, сприяло популяризації історико-краєзнавчого руху в губерніях. Так, у Чернігівській губернії, в земських газетах «Черниговская земская неделя», «Черниговская земская газета», «Черниговский край», «Земский сборник Черниговской губернии» та інших, систематично друкувалися добірки історичних документів, наукові розвідки, пам'ятки фольклору тощо [7].

Отже, земства відігравали, без перебільшення, провідну позитивну роль у створенні та подальшій діяльності більшості місцевих краєзнавчих осередків в губерніях Лівобережної України. Практично 3 початку свого існування, земські установи розгорнули активну краєзнавчу роботу, що мало суттєве позитивне значення для системного поширення історико-краєзнавчого руху в даних губерніях. Присутність у складі земств низки дослідників-краєзнавців зумовила, насамперед, історико-краєзнавчий напрям в роботі цих органів місцевого самоврядування, а також високий фаховий рівень здійснених досліджень із локальної історії.

\section{ЛІТЕРАТУРА}

1. Бабенко В. Вовчанський культурно-історичний окружний музей // Украӥнський музей. Збірник. K., 1927. Ч. 1. C. 241.

2. Вайнштейн М. Конотопський округовий музей // Украӥнський музей. К., 1927. Ч. 1. С. 253.

3. Данилевский Г. П. Доклад Городской думе по вопросу об открытии промышленно-художест- венного музея в г. Харькове. История вопроса. (Отд. оттиск). С. 1-5.

4. ДАХО. Ф. 304. Оn. 1. Спр. 463. Переписка с Предварительным комитетом по устройству ХII археологического съезда в городе Харькове об ассигновании ему денежного пособия на организациюю этнографической выставки к съезду. 
5. К открытию в г. Глухове Черниговской губернии собрания предметов местной старины // Археологическая летопись Южной России. 1903. № 1/6. C. 62-64.

6. Каталог виставки ХІV Археологічного з 'ізду в м. Чернігові. Чернігів, 1908. С. 1-50.

7. Коваленко О. Головні етапи розвитку історичного краєзнавства на Чернігово-Сіверщині // Краєзнавство. № 1-2. 2000. С. 39-45.

8. Малиневская В. М. Развитие исторического краеведения на Черниговщине в конце XIX - нач. XX вв.: Автореф. ... канд. ист. Наук. Киев, 1990. 17 с.

9. Полтавский земский музей // Киевская старина. 1894. Кн. XI. C. 307-309.
10. Проект Конотопского уездного земского музея // Киевская старина. 1900. Октябрь.

11. Скрипник Г.А. Етнографічні музеї України. Становлення і розвиток. Киї: Наукова Думка, 1989. $304 \mathrm{c}$.

12. Труды Полтавской ученой архивной комиссии. / Под ред. Л. В. Падалки, И. Ф. Павловского.- Вып. 1-15. Полтава: Тип. Г. И. Маркевича, 1906-1917.

13. Труды Черниговской губернской архивной комиссии 1897-1898. Отдел первый. Чернигов: Типогр. Губ. Правления.

14. Труды ХII археологического съезда в Харькове. 1902 г. Т. ІІІ. / Под ред. Графини П.С.Уваровой. Москва, 1905.

15. Южный край. 1902.

\section{REFERENCES}

1. Babenko V. (1927) Vovchans'kyy kul'turno-istorychnyy okruzhnyy muzey [Vovchansky cultural and historical district museum] Ukrayins'kyy muzey. Zbirnyk. K. CH. 1. S. 241 [in Ukrainian].

2. Vaynshteyn M. (1927) Konotops'kyy okruhovyy muzey [Konotop District Museum] Ukrayins'kyy muzey. Zbirnyk. K. CH. 1. S. 253 [in Russian].

3. Danilevskiy G.P. (1882) Doklad Gorodskoy dume po voprosu ob otkrytii promyshlenno-khudozhestvennogo muzeya v g. Khar'kove. Istoriya voprosa. [Report to the City Duma on the opening of an industrial and art museum in Kharkov. History of the issue]. (Otd. ottisk). H. S. 1-5 [in Russian].

4. Perepiska s Predvaritel'nym komitetom po ustroystvu XII arkheologicheskogo s"yezda v gorode Khar'kove ob assignovanii yemu denezhnogo posobiya na organizatsiyu etnograficheskoy vystavki k s"yezdu. [Correspondence with the Preliminary committee for the arrangement of the 12th archaeological congress in the city of Kharkov on the allocation of a monetary allowance for organizing an ethnographic exhibition for the congress.] Derzhavnyi arkhiv Kharkivskoi oblasti - State Archive of Kharkiv Oblast (F. 304. Op. 1. Spr. 463) [in Russian].

5. K otkrytiyu v g. Glukhove Chernigovskoy gubernii sobraniya predmetov mestnoy stariny (1903) [For the opening of a collection of local antiquities in the city of Glukhov, Chernigov province] Arkheologicheskaya letopis' Yuzhnoy Rossii. № 1/6. S. 62-64 [in Russian].

6. Kataloh vystavky KHIV Arkheolohichnoho z"yizdu v m. Chernihovi (1908) [Catalog of the exhibition of the XIV Archaeological Congress in Chernihiv] Chernihiv. S. 1-50 [in Ukrainian].

7. Kovalenko O. (2000) Holovni etapy rozvytku istorychnoho krayeznavstva na Chernihovo-Sivershchyni
[The main stages of development of historical local lore in Chernihiv-Sivers'kyi region] Krayeznavstvo, № 1-2. S. 39-45 [in Ukrainian].

8. Malinevskaya V.M. (1990) Razvitiye istoricheskogo krayevedeniya na Chernigovshchine $\mathrm{v}$ kontse KHÍKH - nach. KHKH vv. [The development of historical local lore in the Chernihiv region at the end of XIX - beginning. XX centuries] Avtoref. ...kand. ist. nauk, Kiyev. 17 s. [in Russian].

9. Poltavskiy zemskiy muzey (1894) [Poltava Zemstvo Museum] Kiyevskaya starina Kn. KHÍ. S. 307-309 [in Russian].

10. Proyekt Konotopskogo uyezdnogo zemskogo muzeya (1900) [Project of Konotop County Zemstvo Museum] Kiyevskaya starina. Oktyabr' [in Russian].

11. Skrypnyk H.A. (1989) Etnohrafichni muzeyi Ukrayiny. Stanovlennya i rozvytok. [Ethnographic museums of Ukraine. Formation and development]. Kyyiv, Naukova Dumka. 304 s. [in Ukrainian].

12. Trudy Poltavskoy uchenoy arkhivnoy komissii. (1906-1917) [Proceedings of the Poltava Scientific Archive Commission]. Pod red. L.V.Padalki, I.F.Pavlovskogo. Vyp. 1-15. Poltava: Tip. G.I.Markevicha [in Russian].

13. Trudy Chernigovskoy gubernskoy arkhivnoy komissii (1897-1898) [Proceedings of the Chernigov Provincial Archival Commission]. Otdel pervyy - Chernigov: Tipogr. Gub. Pravleniya [in Russian].

14. Trudy XII arkheologicheskogo s"yezda v Khar'kove. 1902 g. (1905) [Proceedings of the XII Archaeological Congress in Kharkov. 1902] T. III. / Pod red. Grafini P.S.Uvarovoy. Moskva [in Russian].

15. Yuzhnyy kray (1902) [South edge] [in Russian]. 